\title{
ANALISISTERJEMAHAN IDIOM PADA MAHASISWA SEMESTER IV PENDIDIKAN BAHASA INGGRIS FKIP UNISRI 2019
}

\author{
Sumardiono ${ }^{1}$ \\ Ulupi Sitoresmi ${ }^{2}$ \\ Prodi Pendidikan Bahasa Inggris FKIP UNISRI ${ }^{1,2}$ \\ sumardionozy@gmail.com \\ ulupisitoresmi27@gmail.com
}

\section{PENDAHULUAN}

Karena idiom adalah bagian dari bahasa figuratif yang tidak bisa dipahami secara literal, pemahaman tentang makna yang dikandung dari idiom tidak sederhana. Sebuah idiom mengekspresikan sebuah sentimen tertentu. Idiom juga bersifat spesifik dalam sebuah bahasa dan tidak selalu bisa ditemukan padanannya dalam bahasa lain sehingga sebuah idiom tdak bisa diterjemahkan negitu saja dari sebuah bahasa ke dalam bahasa lain. Tentu saja, sebuah idiom tidak bisa dipahami begitu saja dari unit-unit bahasa pembentuknya. Idiom memiliki pesan yang jauh lebih besar dari konstituen-konstituen penyusunnya.

Idiom bersifat terikat secara kultural sehingga penerjemahan sebuah idiom harus melalui pemahaman budaya yang melatarbelakanginya. Seorang penerjemah dituntut untuk memiliki pemahaman budaya yang baik dari bahasa sumber. Perlu strategi-strategi khusus untuk bisa mendapatkan terjemahan yang memiliki tingkat keakuratan dan keberterimaan yang tinggi.

\section{METODOLOGI}

Penelitian ini adalah deskriptif kualitatif, terpancang dan berkasus tunggal. Sumber data dari penelitian ini terjemahan idiom yang dilakukan oleh mahasiswa Pendidikan Bahasa Inggris semester empat Universitas Slamet Riyadi Surakarta. Metode pengumpulan data yang digunakan dalam penelitian ini adalah pengkajian dokumen dan focus group discussion. Peneltian ini menerapkan teknik sampling bertujuan atau purposed sampaling. Data yang diperoleh lewat pengkajian dokumen/content analysis adalah teks bahasa sumber idiom dan terjemahannya serta teknik penerjemahan dan kualitas terjemahan.

\section{TEMUAN DAN PEMBAHASAN}

\section{I.Teknik Penerjemahan}

Untuk mengetahui bagaimana idiom Bahasa Inggris diterjemahkan kedalam Bahasa Indonesia, digunakan analisis teknik penerjemahan. Secara keseluruhan terdapat 13 variasi teknik penerjemahan. Namun dalam penelitian ini hanya ada lima variasi yaitu Explisitasi, Padanan Lazim, Literal, Kreasi Diskursif dan Deletion. Masing-masing menunjukkan frekuensi penggunaan yang berbeda-beda. Teknik yang paling banyak diterapkan yaitu Explisitasi. Sementara yang paling sedikit yaitu Deletion. Tabel berikut menunjukkan variasi teknik dan frekuensinya.

Tabel 4.1 Teknik Penerjemahan 


\begin{tabular}{|l|l|l|}
\hline No & Teknik & Jumlah \\
\hline 1. & Explisitasi & 95 \\
\hline 2. & $\begin{array}{l}\text { Kreasi } \\
\text { Diskursif }\end{array}$ & 34 \\
\hline 3. & $\begin{array}{l}\text { Padanan } \\
\text { Lazim }\end{array}$ & 8 \\
\hline 4. & Literal & 8 \\
\hline 5. & Deletion & 5 \\
\hline
\end{tabular}

Dari 150 data yang dianalisis terdapat lima jenis teknik yang dipilih penerjemah.

\subsection{Teknik Explisitasi}

Teknik ini paling banyak diterapkan oleh penerjemah. Terdapat 95 data dari total 150. Berikut contoh terjemahan idiom dengan teknik Explisitasi:

Bsu “ By taking my Dad on holiday, I killed two birds with one stone. I got to go away but also spend time with him"

BSa Dengan mengajak ayahku berlibur, saya menyelesaikan dua masalah

sekaligus. Saya harus pergi tetapi juga menghabiskan waktu bersamanya.

Dari contoh diatas idiom I killed two birds with one stone diterjemahkan menjadi "Saya menyelesaikan dua masalah sekaligus". Tekinik ini diterapkan untuk memunculkan pesan yang tidak akan tersampaikan jika penerjemah menerapkan teknik literal. Pesan yang dieksplisitkan yaitu "menyelesaikan dua masalah dalam satu waktu/sekaligus".

\subsection{Teknik Kreasi Diskursif}

Teknik ini menjadi pilihan kedua setelah Explisitasi. Terdapat 34 data dari total 150. Berikut contoh data idiom yang diterjemahkan dengan teknik Kreasi Diskursif.

$\mathrm{BSu}$ “Break a leg Sam, I'm sure your performance will be great"

BSa Pelankan panggung itu Sam,aku yakin penampilanmu akan lebih

$$
\text { baik lagi. }
$$

Teknik ini mmungkinkan terjemahan nampak sangat berbeda. "Break a leg" tidak ada hubungan langsung dengan "panggung". Pesan yang ingin disampaikan BSu yaitu meminta Sam beristirahat sejenak.

\subsection{Teknik Padanan Lazim}

Teknik ini ditemukan sejumlah delapan kali dari 150. Berikut contohnya.

$\mathrm{BSu}$ " I let the cat out of the bag about their wedding plan"

\section{BSa Saya tidak sengaja membocorkan} rencana pernikahan mereka.

Teknik ini acapkali disebut terjemahan baku. Pada contoh ini " I let the cat out of the bag" diterjemahkan menjadi "Saya tidak sengaja membocorkan rencana pernikahan mereka.

\subsection{Teknik Literal}

Teknik ini muncul delapan kali dari 150 data.Berikut salahsatu contoh penerapan teknik ini.

$\mathrm{BSu}$ "I only go to the cinema once in a blue moon " 
BSa Aku hanya pergi ke bioskop sekali di bulan biru

Teknik Literal acapkali disebut sebagai teknik penerjemahan harfiah.

Penerjemah mengalihkan makna apa adanya. Dari contoh di atas "... once in a blue moon" diterjemahkan menjadi “... sekali di bulan biru". Sementara yang dimaksut disini adalah “ jarang”.

\subsection{Teknik Penghapusan (Deletion)}

Teknik ini ditemukan sebanyak lima data dari 150. Berikut salah satu contoh terjemahan idiom dengan teknik Penghapsan.

$\mathrm{BSu}$ “ To add insult injury the car drove off without stopping after knocking

$$
\text { me off my bag" }
$$

BSa Mobil itu tetap tidak berhenti setelah menabrak sepeda saya.

Teknik ini berujung pada tidaktersampaikannya pesan dari BSu ke BSa karena ada informasi yang dihilangkan yaitu "To add insult injury"

\section{Kualitas Terjemahan}

Kualitas terjemahn idiom

Untuk mengukur kualitas terjemahan idiomatic expressionpada penelitian ini didasarkan pada tingkat keakuratan, keberterimaan, dan keterbacaan.

\subsection{Tingkat Keakuratan}

Tiga skala digunakan untuk mengukur tingkat keakuratan. Tingkat tertinggi diberi nilai 3(akurat) dimana pesan idiom pada $\mathrm{BSu}$ tersampaikan sepenuhnya

kedalam BSa. Jika pesan idiom BSu tidak tersampaikan sepenhnya diberi nilai 2(kurang akurat). Sementara nilai 1(tidak akurat) diberikan apabila pesan idiom tidak tersampaikan. Berikut merupakan contohcontoh penilaian tersebu

\subsubsection{Terjemahan Akurat}

$\mathrm{BSu}$ "By working part time and looking after her kids two days a week she managed to get the best of both worlds"

BSa Sambil bekerja sampingan dan menjenguk anak-anaknya dalam seminggu, dia dapat memanfaatkan dua hal sekaligus dengan baik/melampaui dua pulau dalam sekali mendayung

2.1.2 Terjemahan Kurang Akurat

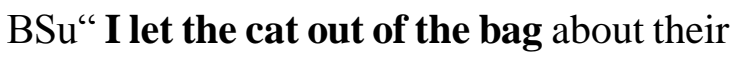
wedding plan"

BSa Saya membiarkan kucing keluar

dari kandang tentang rencana pernikahan mereka.

2.1.3 Terjemahan Tidak Akurat

$\mathrm{BSu}$ " They really cut corners when they built this bathroom. The shower is leaking" Bsa Mereka sungguh memotong sudutnyaketika mereka membangun kamar mandi. Showernya bocor.

Pada contoh ketiga penerjemah menerapkan teknik penerjemahan literal yaitu menerjemahkan apa adanya sehingga pesan "cut the corners" tidak tersampaikan.

\subsection{Tingkat Keberterimaan}

Tingkat Keberterimaan diukur dari seberapa tinggi terjemahan memenuhi kaidah Bahasa sasaran, baik gramatikal maupun kultural. Tiga skala diterapkan dalam penilaian ini. Tingkat Keberterimaan tinggi bernilai 3 (Berterima) jika 
terjemahan alamiah sesuai kaidah gramatikal dan kultural

Bahasa Indonesia.Nilai 2 (Kurang Berterima) diberikan jika terjemahan kurang alamiah karena ditemukan kejanggalan pada gramatikal. Sementara nilai 1 (Tidak berterima) diberikan jika terjemahan tidak alamiah dan terasa janggal dalam Bahasa Indonesia. Di bawah ini beberapa contoh penilaian.

\subsubsection{Terjemahan Berterima}

$\mathrm{BSu}$ " Hi Tom, speak of the Devil, I was just telling Sara about your new car"

Bsa Hi Tom, mengejutkan aku baru saja memberitahu Sara mengenai mobil Barumu

\subsubsection{Terjemahan Kurang Berterima}

$\mathrm{BSu}$ "He hit the nail on the head when he said this company needs more HR Support"

BSa Dia menepuk kepala ketika dia bilang perusahaan ini butuh dukungan HR yang lebih.

\subsubsection{Terjemahan Tidak Berterima}

$\mathrm{BSu}$ " To add insult to injury the car drove off without stopping after knocking me off my bike"

BSa Mobil melaju tanpa berhenti setelah menghentikan saya dari sepeda.

\subsection{Tingkat Keterbacaan}

Aspek ketiga penilaian yaitu tingkat keterbacaan. Aspek ini berhubungan dengan pembaca yaitu sejauh mana teks terjemahan mudah dipahami oleh pembaca.Tiga skala diterapkan dalam penilaian ini. Tingkat Keterbacaan tinggi bernilai 3 (mudah dipahami. Nilai 2 (Kurang Mudah Dipahami).Sementara nilai
1 (Sulit). Di bawah ini beberapa contoh penilaian.

2.3.1 Terjemahan Mudah Dipahami

$\mathrm{BSu}$ "Fuel these days cost an arm and a leg"

BSa Bahan bakar hari ini mahal

2.3.2 Terjemahan kurang mudah dipahami

$\mathrm{BSu}$ "I let the cat out of my bag about their wedding plan"

BSa Saya membiarkan kucing keluar dari kandang tentang rencana pernikahan mereka.

\subsubsection{Terjemahan Sulit Dipahami}

$\mathrm{BSu}$ "To add insult to injury the car drove off without stopping after knocking me off my bike"

BSa Mobil itu malah tidak berhenti setelah menabrak jatuh dari sepeda.

\section{B. Pembahasan}

Ada dua hal penting yang perlu diperhatikan ketika menerjemahkan idiom. Yang pertama adalah bentuk dan yang kedua adalah makna. Bentuk meliputi bagaimana sebuah idiom dimanifestasikan dalam bahasa tertentu, sementara itu makna menyangkut pesan yang ingin disampaikan oleh idiom tersebut. Dari terjemahan idiom yang dihasilkan oleh responden terlihat nyata bahwa responden cenderung mementingkan makna dari pada bentuk. Ini terlihat dari teknik yang digunakan oleh responden. Tentu hal ini tidak keliru karena hakekat penerjemahan adalah memindahkan makna dari bahasa sumber ke bahasa sasaran. Hanya ada sedikit kasus responden yang bisa menangkap makna dari idiom dan kemudian mencari padanan 
idiomnya dalam bahasa Indonesia. Sebagian responden menerjemahkan idiom secara literal sehingga kehilangan pesan idiomnya dalam bahasa sasaran. Sebagian lagi gagal menangkap makna dan sebagian kecil menghilangkan sama sekali pesan idiom tersebut.

Dari 150 teknik penerjemahan yang diterapkan, hanya ada 8 teknik padanan lazim yang diterapkan pada penerjemahan idiom. Ini hanya berkisar $5 \%$ dari keseluruhan teknik yang muncul. Teknik inilah yang menghasilkan terjemahan idiom yang paling ideal. Idiom bahasa sumber dicarikan padanan idiom dalam bahasa sasaran yang memiliki pesan paling mendekati. Teknik ini memiliki kualitas terjemahan yang paling tinggi baik dari segi keakuratan, keberterimaan maupun keterbacaan.

Pada sebagian besar responden, nyata mereka bisa menangkap makna dari idiom bahasa sumber. Meskipun begitu, mereka gagal menemukan padanan idiom yang lazim dalam bahasa sasaran. Sebagai gantinya, mereka mengeksplisitkan makna idiom tersebut kedalam bahasa sasaran. Teknik eksplisitasi muncul sebanyak $63 \%$ dari total teknik yang muncul. Teknik ini menghasilkan terjemahan yang sudah mengakomodasi pesan teks bahasa sasaran, tidak ada pergeseran makna yang terjadi pada teks terjemahan meskipun terjemahan tidak menghasilkan idiom padanan dalam bahasa sasaran. Teknik ini masih menghasilkan terjemahan dengan kualitas tinggi, baik dari sisi keakuratan, keberterimaan maupun keterbacaan.

Sebagian koresponden gagal memaknai idiom sebagai sebuah idiom sehingga mereka cenderung menerjemahkannya secara literal. Teknik ini meliputi 5\% dari total teknik yang diterapkan. Teknik literal menghasilkan terjemahan dengan kualitas yang rendah baik dari sisi keakuratan, keberterimaan maupun keterbacaan.

Beberapa responden gagal memahami makna sama sekali sehingga menghasilkan terjemahan yang tidak akurat. Teknik ini meliputi $23 \%$ dari total 150 teknik yang diterapkan. Teknik kreasi diskursif menunjukan kegagalan penerjemah memahami pesan yang tersirat dari idiom dalam bahasa sasaran. Teknik ini menghasilkan terjemahan dengan tingkat keakuratan yang rendah.

Meskipun tidak banyak, ada beberap responden yang menghapus pesan idiom dalam teka bahasa sasaran. Ini bisa terjadi karena penerjemah gagal menangkap pesan idiom dalam teks bahasa sasaran. Teknik delesi memiliki kualitas paling buruk di antara semua teknik penerjemahan.

Dari kombinasi lima teknik yang diterapkan; padanan lazim, eksplisitasi, literal, kreasi diskursif dan delesi, dihasilkan terjemahan idiom dengan tingkat keakuratan yang agak rendah 2,3, keberterimaan yang tinggi 2,88 dan keterbacaan yang tinggi pula 2,9

\section{KESIMPULAN}


Analisis hasil penelitian dan pembahasan menghasilkan kesimpulan yang disarikan sebagai berikut:

1. Dari terjemahan idiom yang dihasilkan oleh responden terlihat nyata bahwa responden cenderung mementingkan makna dari pada bentuk. Ini terlihat dari teknik yang digunakan oleh responden. Tentu hal ini tidak keliru karena hakekat penerjemahan adalah memindahkan makna dari bahasa sumber ke bahasa sasaran. Hanya ada sedikit kasus responden yang bisa menangkap makna dari idiom dan kemudian mencari padanan idiomnya dalam bahasa Indonesia. Sebagian responden menerjemahkan idiom secara literal sehingga kehilangan pesan idiomnya dalam bahasa sasaran.

2. Ditemukan 5 teknik penerjemahan yang digunakan penerjemah. Beberapa teknik dipakai secara lebih sering dibanding teknik yang lain. Teknikteknik ini secara berurutan berdasarkan frekuensi pemakaian adalah sebagai berikut: Eksplisitas, kreasi diskursif, padanan lazim, literal dan delesi.

3. Dari kombinasi lima teknik yang diterapkan; padanan lazim, eksplisitasi, literal, kreasi diskursif dan delesi, dihasilkan terjemahan idiom dengan tingkat keakuratan yang

\section{DAFTAR PUSTAKA}

Baker, Mona. 1992. In Other Words. London and Newyork: RoutLedge.
Catford, J. C. 1980. A Linguistic Theory of Translation. London: Oxford University Press.

Coulthard, M. 1985. An Introduction to Discourse Analysis. New York: Addison Wesley Longman.

Larson, Mildred A. 1984. Meaning-Based Translation. Lanham: University Press of America.

Machali, Rochayah. 2000. Pedoman bagi Penerjemah. Jakarta: Grasindo.

Moleong, Lexy J. 2005. Metodologi Penelitian Kualitatif. Bandung : Rosda

Nasir, M. 1999. Metode Penelitian. Jakarta: Galia Indonesia

Newmark, Peter. A text Book of Translation. Singapore:Prentice Hall Radford, Andrew. 1988. Transformational Grammar. New York: Cambridge University Press.

Sutopo, H.B. 2006 Metode Penelitian Kualitatif: Dasar Teori dan Terapannya dalam Penelitian. Surakarta: UNS Press. 1988. Pengantar Penelitian kualitatif. Surakarta:UNS press.

Zuchridin Suryawinata dan Sugeng Hariyanto. 2003. Translataion: Bahasan teori dan Penuntun Praktis Menerjemahkan. Yogyakarta: Kanisius. 